\title{
The Analysis of the Effective Systemic Lidocaine Dosage on the Expression of HMGB1 mRNA on Mice with Sterile Musculoskeletal Injury
}

\section{Robert Hotman Sirait ${ }^{1}$, Mochammad Hatta ${ }^{2 *}$, Muhammad Ramli ${ }^{3}$, Tigor Peniel Simanjuntak ${ }^{4}$ Bambang Suprayogi ${ }^{5}$, Andi Asadul Islam6, Syafrie Kamsul Arief ${ }^{3}$}

\begin{abstract}
${ }^{1}$ Department of Anesthesiology, Faculty of Medicine, Christian University of Indonesia, Jakarta, Indonesia
${ }^{2}$ Molecular Biology and Immunology Laboratory, Faculty of Medicine, University of Hasanuddin, Makassar, Indonesia

${ }^{3}$ Department of Anesthesiology, Faculty of Medicine, University of Hasanuddin, Makassar, Indonesia

${ }^{4}$ Department of Obstetric and Gynecology, Faculty of Medicine, Christian University of Indonesia, Jakarta, Indonesia

${ }^{5}$ Department of Otorhinolaryngology, Faculty of Medicine, Christian University of Indonesia, Jakarta, Indonesia

${ }^{6}$ Department of Surgery, Faculty of Medicine, University of Hasanuddin, Makassar, Indonesia
\end{abstract}

Email: *hattaram@indosat.net.id

How to cite this paper: Sirait, R.H., Hatta, M., Ramli, M., Simanjuntak, T.P., Suprayogi, B., Islam, A.A. and Arief, S.K. (2017) The Analysis of the Effective Systemic Lidocaine Dosage on the Expression of HMGB1 mRNA on Mice with Sterile Musculoskeletal Injury. Open Journal of Anesthesiology, 7, 35-41.

https://doi.org/10.4236/ojanes.2017.72004

Received: January 19, 2017

Accepted: February 24, 2017

Published: February 27, 2017

Copyright $\odot 2017$ by authors and Scientific Research Publishing Inc. This work is licensed under the Creative Commons Attribution International License (CC BY 4.0). http://creativecommons.org/licenses/by/4.0/ (c) (i) Open Access

\begin{abstract}
A severe injury can trigger an inflammation response and excessive response can cause multiple organ failure. HMGB1 is an early inflammation mediator in sterile injury and a late inflammation mediator in infection. It is an impor- tant mediator in severe sepsis and always associated with the severity of organ failure. Previous studies showed that the administration of systemic lidocaine could inhibit the expression of HMGB1 on septic mice with musculoskeletal injury. Nine male adult $\mathrm{Balb} / \mathrm{c}$ mice were grouped by simple random sampling method into three groups of intravenous lidocaine injection dosages: $2 \mathrm{mg} / \mathrm{kg}$, 3 $\mathrm{mg} / \mathrm{kg}, 4 \mathrm{mg} / \mathrm{kg}$. Musculoskeletal injury was done by breaking the left femo- ral bone in a close manner. Peripheral blood sampling was done 4 hours after injury and 2 hours after lidocaine therapy. To evaluate the expression level of HMGB1 mRNA, RT-PCR was used. The result of our study showed that intravenous lidoaine administration on the 3 groups could decrease the level of HMGB1. In conclusion, lidocaine hold an important role in clinical diseases by inhibiting HMGB1.
\end{abstract}

\section{Keywords}

High Mobility Group Box 1, Lidocaine, Musculoskeletal Injury

\section{Introduction}

A severe injury can trigger an inflammation response and excessive response can 
produce multiple inflammation cytokines that can activate the systemic response in term of systemic inflammation response syndrome (SIRS). SIRS can affect the vascular permeability, and the function of heart, lungs, liver, kidneys, intestines, and other organs; and induce metabolic changes that can cause multiple organ failure (MOF), septic shock, and even death [1] [2] [3].

Previous study showed that inflammation cytokine like high mobility group box 1 (HMGB1) was always associated with organ worsening [2] [4]. HMGB1 is a nuclear protein that has been known as transcription and growth factor [5] [6] [7]. HMGB1 is an important inflammation mediator in sepsis and the level is increased in major surgery procedures [8] [9] [10].

Lidocaine is a local anaesthetic from amide group that has been long known and used in clinical practice to prevent surgical pain and reduce the pain from disease proccess. Lidocaine also has anti-arrythmic and anti-inflammation properties. In the last decades, the anti-inflammation property of lidocaine had been used to treat septic mice and protect against organ failure from its ability to inhibit the expression of macrophage HMGB1 [11]-[16].

The purpose of this study is to analyze the effectivity of systemic lidocaine dosages of $2 \mathrm{mg} / \mathrm{kg}$ body weight, $3 \mathrm{mg} / \mathrm{kg}$ body weight, and $4 \mathrm{mg} / \mathrm{kg}$ body weight on the expression of mice Balb/c mice with closed femoral fracture.

\section{Material and Methods}

This is a longitudinal laboratory experiment on animals, using nine Balb/c mice. The inclusion criteria including: healthy male Balb/c mice, body weight $35-40$ grams, aged 7 - 8 weeks. Healthy Balb/c mice are mice with shiny eyes, undull fur, active movement, and good appetite. Dead mice on this study process will be excluded. Mice were obtained from the maintenance and development unit of experimental animal laboratory in Faculty of Medicine, Hasanuddin University, Makassar, Indonesia. These experimental animals were adapted and carried out according to the Declaration of Helsinki.

The sample size was determined simply according to the Ethical Committee of Animal Experiment in Hasanuddin University Faculty of Medicine, Makassar, Indonesia. Every group consisted of 3 mice. The study was conducted in Molecular Biology and Immunology laboratory in Hasanuddin University Faculty of Medicine Makassar on August 2015. The lidocaine used was 2\% isobaric lidocaine, produced by Kimia Farma Indonesia. The intervention manner was adjusted with the mice taking manner from its cages.

Firstly, $0.3 \mathrm{ml}$ venous blood was taken from every mice' tails to evaluate the initial expression of HMGB1 mRNA (Group I), then the mice were anaesthesized by injecting $50 \mathrm{mgs} / \mathrm{kg}$ body weight of Ketamine intraperitoneally. After that, mice left femoral bone were broken in a close manner using 2 Kocher, and after 4 hours $0.3 \mathrm{cc}$ blood was taken (Group II). Mice were injected with systemic lidocaine every 2 hours for 24 hours from the tail veins with dosages of 2 $\mathrm{mgs} / \mathrm{kg}$ body weight, $3 \mathrm{mgs} / \mathrm{kg}$ body weight, and $4 \mathrm{mgs} / \mathrm{kg}$ body weight. Two hours after lidocaine therapy, $0.3 \mathrm{cc}$ mice blood were drawn again for the third 
examination (Group III). All blood samples were mixed with L6 solution to be processed into nucleic acid extract and stored $-80^{\circ} \mathrm{C}$ temperature.

\subsection{Real-Time Polymerase Chain Reaction (RT-PCR) Analysis}

RT-PCR analysis was done by making specific primers PCR mixture as much as $22.5 \mu \mathrm{l}$. And then $1 \mu \mathrm{M}$ concentrations of the forward and reverse specific primers of mice HMGB1 gene were added (HMGB1 for, 5'-CGTCTGGCTCCCGCTCTCACA-3' and Rev: 5'-GAGTCGCCCAGTGCCCGTC-3'. Beta actine: for: 5'-CTGAGAGGGAAATCGTGCGT-3' and Rev: 5'-CCACAGGATTCCATAC CCAAGA3 as housekeeping gene). After that, about $2.5 \mu \mathrm{DNA}$ extract was added into the $22.5 \mu \mathrm{l}$ specific PCR mixture and first stage amplification was done with $94^{\circ} \mathrm{C}$ for 2 minutes and continued by 40 cycles of 60 seconds in $94^{\circ} \mathrm{C}, 45$ seconds in $57^{\circ} \mathrm{C}$, using Real time PCR machine (Bio-Rad CFX Connect, USA). The PCR result was detected using SYBR Green and analyzed using Bio-Rad CFX Manager 3.1 software Statistical Analysis. Normal distribution data was expressed in mean \pm SD. The data was analyzed using ANOVA test or its alternative with significance level of $\mathrm{p}<0.05$.

\section{Results}

The mean weight of the 9 mice from the 3 experimental mice was: control group 36.2 grams, intervention group 37.466 grams, and therapeutic group 38.8 grams. There was no significant difference in the mice weight in the 3 experimental groups $(\mathrm{p}<0.05)$.

The expression of HMGB1 mRNA had been detected by RT-PCR examination before the breaking of left femoral bone. The expression of HMGB1 mRNA level in Group I: early $7.05 \pm 0.081$; intervention $12.653 \pm 0.477$; after lidocaine therapy $7.185 \pm 0.045$. In Group II, the expression of HMGB1 mRNA was: early $6.968 \pm 0.071$; intervention $12.504 \pm 0.111$; after lidocaine therapy $6.402 \pm 0.100$. In Group III, the expression of HMGB1 mRNA: early $6.981 \pm 0.105$; intervention $12.501 \pm 0.066$; after lidocaine therapy $6.164 \pm 0.129$. The expression of HMGB1 mRNA level was markedly increased in 4 hours after left femoral bone fracture. The high level of HMGB1 mRNA was significantly decreased for 24 hours after systemic lidocaine therapy $(\mathrm{p}<0.05)$. The result of HMGB1 mRNA expression profile in mice blood can be seen in Table 1.

Figure 1 revealed that the intravenous lidocaine administration by doses 2 $\mathrm{mg} / \mathrm{kg}, 3 \mathrm{mg} / \mathrm{kg}, 4 \mathrm{mg} / \mathrm{kg}$ on the 3 groups significant decrease of the level HMGB1.

\section{Discussion}

Inflammation response is a very complex series of events involving many inflammation, anti-inflammation process, humoral and celullar process that will cause metabolic abnormality in systemic circulation [3] [4] [17] [18] [19] [20]. Continuous and excessive inflammation response will cause multiple organ failure that can cause death [2] [5] [6] [7]. Severe injury will stimulate the body immune system to produce inflammatory cytokines, such as TNF $\alpha$, IL1, and HMGB1 [20] 
Table 1. Mean mice HMGB1 mRNA expression profile in each group.

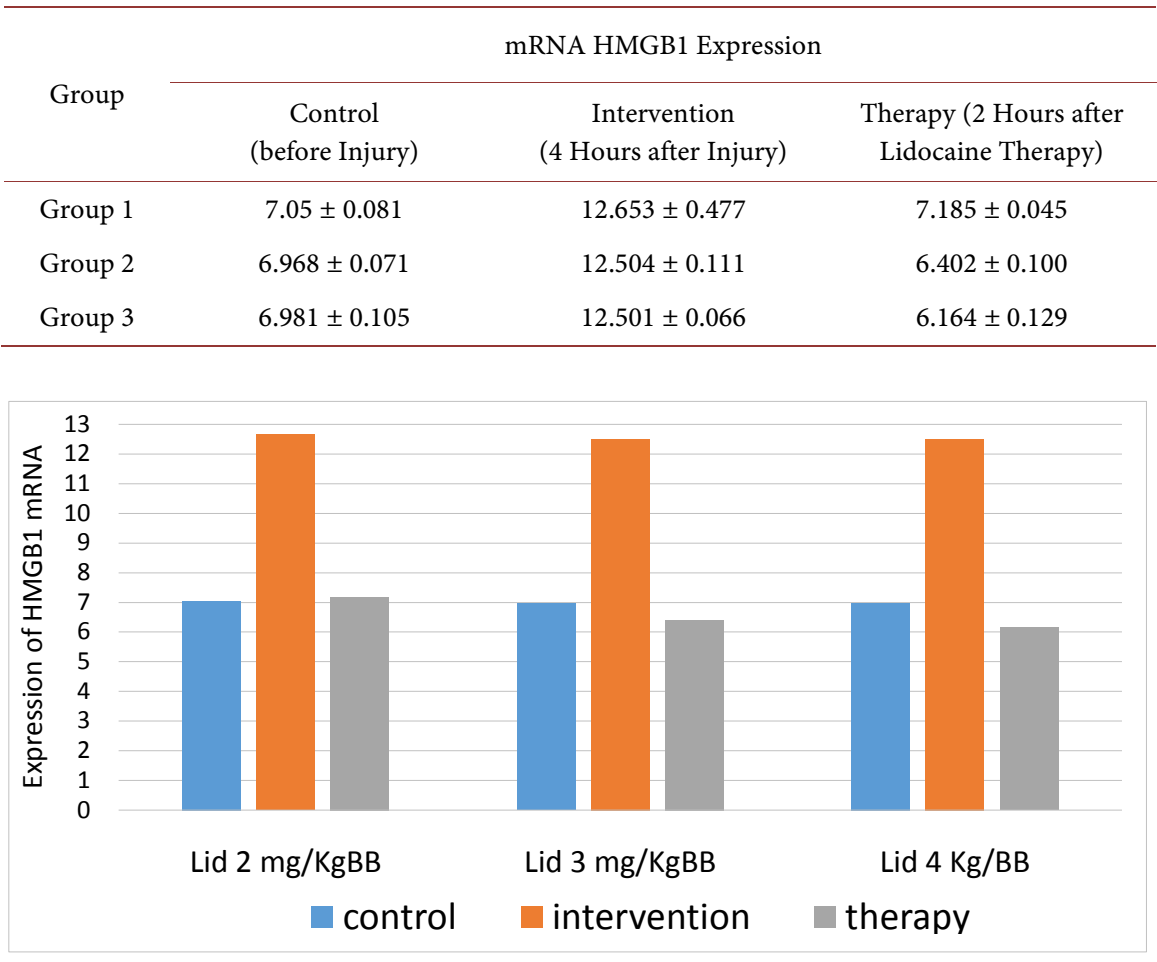

Figure 1. The expression of HMGB1 mRNA in each group $(n=9, p<0.05)$.

[21] [22] [23]. HMGB1 is a non-histone nuclear protein that can be found in almost all mammalian cells and is known to be the early pro-inflammatory mediator in sterile injury and late pro inflammatory mediator in infection [1] [2] [3] [4].

Data of our study showed that HMGB1 mRNA expression can be detected before mice underwent close femoral fracture, and the level will be increased after the mice underwent left femoral bone fracture. Increased level of HMGB1 mRNA expression was detected 4 hours after left bone fracture. The result of this study was consistent with previous studies which showed that increased HMGB1 level can be detected on the end of surgery and can last up to 2 days after liver resection surgery or on the first day of heart bypass procedure.

Lidocaine is a traditional local anaesthetic that has been long used as analgesic and anti-arrythmia. The anti inflammatory property of lidocaine has long been known and proved useful in the treatment of chronic diseases, such as rheumatic arthritis and colitis [10] [11] [12] [13] [14].

The result of our study showed that the administration of systemic lidocaine in dosages of $2 \mathrm{mgs} / \mathrm{kg}$ body weight, $3 \mathrm{mgs} / \mathrm{kg}$ body weight, and $4 \mathrm{mgs} / \mathrm{kg}$ body weight every 2 hours for 24 hours after musculoskeletal injury can decrease the expression of HMGB1 mRNA up to the initial level before mice underwent musculoskeletal injury.

The result of lidocaine therapy in this study was consistent with previous studies on septic experimental animals which was induced with lipopolysaccharides 
(LPS) or cecal ligation and puncture (CLP). The administration of lidocaine can inhibit the production of HMGB1 and protect mice against septic shock [24] [25] [26] [27] [28]. We conclude that lidocaine is useful and has an important role in the management of many clinical diseases by inhibiting the production and release of HMGB1 in pathological condition.

\section{References}

[1] Andersson, U. and Tracey, K.J. (2011) HMGB1 Is a Therapeutic Target for Sterile Inflammation and Infection. Annual Reviews of Immunology, 29, 1-735. https://doi.org/10.1146/annurev-immunol-030409-101323

[2] Harris, H.E., Andersson, U. and Pisetsky, P.S. (2012) HMGB1: A Multifunctional Alarming Driving Autoimmune and Inflammatory Disease. Nature Reviews Rheumatology, 8, 195-202. https://doi.org/10.1038/nrrheum.2011.222

[3] Magna, M. and Pisetsky, D.S. (2014) The Role of HMGB1 in the Pathogenesis of Inflammatory and Autoimmune Disease. Molecular Medicine, 20, 138-146. https://doi.org/10.2119/molmed.2013.00164

[4] Ueda, T. and Yoshida, M. (2010) HMGB1 Proteins and Transcriptional Regulation. Biochim Biophys Acta, 1799, 114-118. https://doi.org/10.1016/j.bbagrm.2009.11.005

[5] Yanai, H., Ban, T., Wang, Z., Choi, M.K., Kawamura, T., Negshi, H., Nakasato, M., Lu, Y., Hangai, S., Koshiba, R., Savitsky, D., Ronfani, L., Akira, S., Bianchi, M.E., Honda, K., Taruma, T., Kodama, T. and Taniguchi, T. (2009) HMGB Proteins Function as Universal Sentinels for Nucleic-Acid-Mediated Innate Immune Responses. Nature, 462, 99-103. https://doi.org/10.1038/nature08512

[6] Hreggvidsdottir, H.S., Ostberg, T., Wahamaa, H., et al. (2009) The Alarmin HMGB1 Acts in Synergy with Endogenous and Exogenous Danger Signal to Promote Inflammation. Journal of Leukocyte Biology, 86, 655-662. https://doi.org/10.1189/jlb.0908548

[7] Scaffidi, P., Mistell, T. and Bianchi, M.E. (2002) Release of Chromatin Protein HMGB1 by Necrotic Cells Triggers Inflammation. Nature, 418, 191-195. https://doi.org/10.1038/nature00858

[8] Hollmann, M.W. and Durieux, M.E. (2000) Local Anesthetics and the Inflammatory Response: A New Therapeutic Indication? Anesthesiology, 93, 858-875. https://doi.org/10.1097/00000542-200009000-00038

[9] Tomori, H., Shiraishi, M., Koga, H., Toure, M., Taira, K., Higa, T., Okuhama, Y., Hiroyasu, S. and Muto, Y. (1998) Protective Effects of Lidocaine in Hepatic Ischemia/ Reperfusion Injury in Vitro. Transplantation Proceedings, 30, 3740-3742. https://doi.org/10.1016/S0041-1345(98)01217-2

[10] Tian, J., Avalos, A.M., Mao, S.Y., Chan, B., Senthil, K., Wu, H., Parocche, P., Drabic, S., Gollenbock, D., Sirois, C., Ua, J., An, L.L., Audoly, L., LaRossa, G., Bierhaus, A., Nawerd, W., Marshak-Rothstein, A., Crow, M., Fitzgerald, K., Latz, E., Khiner, P. and Choile, A.J. (2007) Toll-High Like Receptor 9 Dependent Activation by DNAContaining Immune Complex Is Mediated by HMGB1 and RAGE. Nature Immunology, 8, 487-496. https://doi.org/10.1038/ni1457

[11] Berger, C., Rossaint, J., Aken, H.V., Westphal, M., Hanenkamp, K. and Zarbock, A. (2014) Lidocain Reduces Neutrophil Recruitment by Aboloshing Chemokine-Induced Arrest and Transendothelial Migration in Septic Patients. The Journal of Immunology, 192, 367-376. https://doi.org/10.4049/jimmunol.1301363

[12] Abusoglu, S., Onur, E., Celik, H.T., Guvenc, Y., Sakarya, M., Sakarya, A., Var, A. and Uyanik, B.S. (2013) The Effect of Lidocaine on Liver Tissue Lipid Peroxide Le- 
vels in Septic Rat Model. International Journal of Mevlana Medical Sciences, 1, 31 34.

[13] Caracas, H.C., Maciel, J.V., Martins, P.M., de Souza, M.M. and Maia, L.C. (2009) The Use of Lidocaine as an Anti-Inflammatory Substance: A Systematic Review. Journal of Dentistry, 37, 937. https://doi.org/10.1016/j.jdent.2008.10.005

[14] Nystrom, S., et al. (2013) TLR Activation Regulates Damage-Associated Molecular Pattern Isoforms Released during Pyroptosis. The EMBO Journal, 32, 86-99. https://doi.org/10.1038/emboj.2012.328

[15] Lu, B., Nakamura, T., Inouye, K., Li, J., Tang, Y., Lundback, P., Valdes-Ferrer, S.I., Olofosson, P., Kalb, T., Roth, J., Zou, Y., Erlandsson-Harris, H., Yang, H., Ting, J.P., Wang, H., Andersson, U., Antoine, D.J., Chavan, S.S., Hotamisiligil, G.S. and Tracey, K.J. (2012) Novel Role of PKR in Inflammasome Activation and HMGB1 Release. Nature, 488, 670-674. https://doi.org/10.1038/nature11290

[16] Venereau, E., et al. (2012) Mutually Exclusive Redox Forms of HMGB1 Promote Cell Recruitment or Proinflammatory Cytokine Release. Journal of Experimental Medicine, 209, 1519-1528. https://doi.org/10.1084/jem.20120189

[17] Bell, C.W., Jiang, W., Reich, C.F. and Pisetsky, D.S. (2006) The Extracellular Release of HMGB1 during Apoptotic Cell Death. American Journal of Physiology-Cell Physiology, 291, C1318-C1325. https://doi.org/10.1152/ajpcell.00616.2005

[18] Kim, T.H. and Kang, H. (2011) Intraperitoneal and Intravenous Lidocaine for Effective Pain Relief after Laparascopic Appendectomy: A Prospective, Randomized, Double-Blind, Placebo-Kontrolled Study. Surgical Endoscopy, 25, 3183-3190. https://doi.org/10.1007/s00464-011-1684-3

[19] Liu, J., Zhang, H., Qi, Z. and Zheng, X. (2013) Lidocaine Protects against Renal and Hepatic Dysfunction in Septic Mice via Downregulation of Toll-Like Receptor 4. Molecular Medicine Reports, 9, 118-124.

[20] Gallos, G., Jones, D.R., Nasr, S.H., Emala, C.W. and Lee, H.T. (2004) Local Anesthetics Reduce Mortality and Protect against Renal and Hepatic Dysfunction in Murine Septic Peritonitis. Anesthesiology, 101, 902-911. https://doi.org/10.1097/00000542-200410000-00015

[21] Zetterstorm, C.K., Strand, M.L. and Soder, O. (2006) The High Mobility Group Box Chromosomal Protein 1 Is Expressed in the Human and Rat Testis Where It May Function as Antibacterial Factor. Human Reproduction, 21, 2801-2809. https://doi.org/10.1093/humrep/del256

[22] Fregnan, F., Muratori, L., Simões, A.R., Giacobini-Robecchi, M.G. and Raimondo, S. (2012) Role of Inflammatory Cytokines in Peripheral Nerve Injury. Neural Regeneration Research, 7, 2259-2266. https://doi.org/10.3969/j.issn.1673-5374.2012.29.003

[23] Chamaa, F., Chebaro, M., Safieh-Garabedian, B., Saadeh, R., Jabbur, S.J. and Saadé, N.E. (2016) Transcriptional Expression of Inflammatory Mediators in Various Somatosensory Relay Centers in the Brain of Rat Models of Peripheral Mononeuropathy and Local Inflammation. Journal of Neuroimmunology, 297, 81-91. https://doi.org/10.1016/j.jneuroim.2016.05.005

[24] Wang, H.L., Ying, Y.Q., Yu, Y.X., Rong, F., Lei, W.F. and Zhang, W.H. (2013) The Protective Effect of Lidocaine on Septic Mice via the Inhibition of High Mobility Group Box 1 Expression and NF- $\kappa$ B Activation. Mediators of Inflammation, 570, 370. https://doi.org/10.1155/2013/570370

[25] Wang, H.L., Zhang, W.H., Lei, W.F., Zhou, C.Q. and Ye, T. (2011) The Inhibitory Effect of Lidocaine on the Release of High Mobility Group Box 1 in Lipopolysaccha- 
ride-Stimulated Macrophages. Anesthesia \& Analgesia, 112, 839-844. https://doi.org/10.1213/ANE.0b013e31820dca9f

[26] Yang, H., Antonie, D.J., Andersson, U., et al. (2013) The Many Faces of HMGB1: Molecular Structure-Functional Activity in Inflammation, Apoptosis, and Chemotaxis. Journal of Leukocyte Biology, 93, 865-873. https://doi.org/10.1189/jlb.1212662

[27] Yang, H., Hreggvidsdottir, H.S., Palmblad, K., et al. (2010) A Critical Cysteine Is Required for HMGB1 Binding to Toll-Like Receptor 4 and Activation of Macrophage Cytokine Release. Proceedings of the National Academy of Sciences, 107, 1194211947. https://doi.org/10.1073/pnas.1003893107

[28] Wang, H.L., Liu, Y.Y., Yan, H.D., Wang, X.S., Hyang, R. and Lie, W.F. (2014) Intraoperative Systemic Lidocaine Inhibits the Expression of HMGB1 in Patients Undergoing Radical Hysterectomy. International Journal of Clinical and Experimental Medicine, 7, 3398-3403.

Submit or recommend next manuscript to SCIRP and we will provide best service for you:

Accepting pre-submission inquiries through Email, Facebook, LinkedIn, Twitter, etc. A wide selection of journals (inclusive of 9 subjects, more than 200 journals) Providing 24-hour high-quality service

User-friendly online submission system

Fair and swift peer-review system

Efficient typesetting and proofreading procedure

Display of the result of downloads and visits, as well as the number of cited articles Maximum dissemination of your research work

Submit your manuscript at: http://papersubmission.scirp.org/

Or contact ojanes@scirp.org 